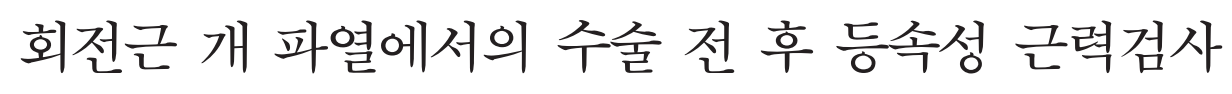

동국대학교 일산병원 정형외과, 동국대학교 경주병원 정형외과*

김진영 · 태석기 · 여도현 · 이호민* · 오종수

\title{
Pre- and Postoperative Isokinetic Strength Test in Rotator Cuff Tear
}

\author{
Jin-Young Kim, M.D., Suk-Kee Tae, M.D., Do-Hyun Yeo, M.D., Ho-Min Lee, M.D.*, Jong-Soo Oh, M.D. \\ Department of Orthopaedic Surgery, Dongguk University Ilsan Hospital, Gyeonggi-do, Korea \\ Dongguk University Gyeongju Hospital, Gyeongsangbuk-do, Korea*
}

\begin{abstract}
Purpose: This study investigated whether (i) isokinetic muscle strength correlated with (ii) anatomical assessment of rotator cuff tear size, fatty degeneration of the supraspinatus muscle or postoperative cuff integrity.
\end{abstract}

Materials \& Methods: Among patients who underwent arthroscopic rotator cuff repair, 32 patients in whom magnetic resonance imaging (MRI) and isokinetic muscle strength tests were performed preoperatively and, at an average of 10 months after repair, took part in this study. We measured the isokinetic strength (peak torque and total work) deficit in external rotation and internal rotation at a $60^{\circ} / \mathrm{sec}$ load.

Results: Preoperative isokinetic strength deficits correlated with tear size $(p<0.001)$ but correlated weakly with fatty degeneration of supraspinatus muscle $(p<0.001)$. In patients with healed rotator cuffs, preoperative peak torque and total work deficits were $39 \%$ and $62 \%$ for external rotation. At final follow up, they were decreased to $17 \%$ and $32 \%$, respectively. In the re-tear group, preoperative peak torque and total work deficit were $44 \%$ and $61 \%$ in external rotation. At final follow up, they were decreased to $23 \%$ and $35 \%$, respectively. But there was no significant difference between the two groups $(p>0.05)$.

Conclusion: Preoperative isokinetic strength correlates with tear size but not fatty degeneration of the supraspintus muscle or postoperative cuff integrity. Postoperative cuff integrity did not have an effect on postoperative isokinetic strength.

Key Words: Rotator cuff, Supraspinatus, Fatty degeneration, Re-tear, Isokinetic strength test

\footnotetext{
※통신저자: 오 종 수

경기도 일산 동구 식사동 814

동국대학교 일산병원 정형외과
}

Tel: 031) 961-7295, Fax: 031) 961-7290, E-mail: comicojs@naver.com

접수일: 2011년 10월 12일, 1차 심사완료일: 2011년 10월 30일, 게재 확정일: 2011년 11월 13일 


\section{서 론}

회전근 개 파열에 대한 외과적 복원은 동통의 완화와 기능의 회복에 좋은 결과를 보이고 있다. ${ }^{1-5)}$ 최근에는 회전근 개 복원술 후 근력의 회복이 임상적 결과를 평 가하는 데 중요한 항목으로 포함되고 있다. ${ }^{3.6-8)}$ 회전근 개 질환의 치료 전 후 근력의 평가로 빠르고 쉽게 시행 할 수 있는 도수 근력검사가 주로 시행되고 있고 있다. 그러나 도수 근력검사는 등척성 근력검사로 검사자의 주관적인 요소가 반영되고 신뢰도가 떨어지는 방법이 다. ${ }^{910)}$ 최근에는 등속성 근력검사가 기능적 운동 범위에 서의 동적인 회전력 (dynamic torsional force)을 측 정함으로서 보다 객관적이고 정확한 근력의 평가로 알 려지고 있다. ${ }^{711}$ 그러나 등속성 근력과 회전근 개 파열 의 크기, 근육의 지방변성, 수술 후 회전근 개의 연속 성 여부와의 관계는 명확하지 않다. 본 연구의 목적은 수술 전 회전근 개의 해부학적 상태와 수술 후 회전근 개의 복원 유지 여부가 등속성 근력검사에 미치는 영향 에 대해서 알아보는데 있다.

\section{연구 대상 및 방법}

\section{1. 연구 대상}

2005년 5월에서 2010년 10월까지 본원에서 관절경적 회전근 개 복원술을 시행한 270 예의 환자 중, 수술 전 등속성 근력검사 및 자기공명영상검사를 시행한 97예 (Table 1)를 대상으로 등속성 근력검사 결과와 파열의
크기 및 극상근의 지방변성과의 상관관계를 연구 하였 다. 수술 후 건의 상태 및 재파열의 발생은 Sugaya의 기준 ${ }^{12)}$ 으로 하여 I, II, III형을 완전 치유된 군으로 하 고 IV, $\mathrm{V}$ 형을 재파열된 군으로 하였다 (Table 2). 수술 후 10 개월 이상 추시 가능하였고 수술 후 추시 자 기공명영상검사을 시행한 69예 (Table 3)를 대상으로 완전 치유된 경우를 I군 (Group I)으로 하고 재파열된 경우를 II군 (Group II)으로 하여 수술 전 등속성 근력 검사와 재파열 여부의 관계에 알아 보았다. 수술 후 자 기 공명영상검사 및 등속성 근력검사 모두를 시행한 32 예 (Table 4)도 완전 치유된 군 (Group A)과 재파열 된 군 (Group B)으로 나누어 수술 후 등속성 근력의 회복 및 재파열이 수술 후 등속성 근력에 미치는 영향 에 대해서 분석하였다. 감염, 견관절 강직, 근력검사를 시행할 수 없을 정도의 통증을 가진 환자는 연구 대상 에서 제외 되었다. 또한 수술을 시행하지 않은 쪽 어깨

Table 1. Patients demographic data and result of isokinetic test

\begin{tabular}{lc}
\hline \hline Variable & Data \\
\hline Tear size \pm SD $(\mathrm{cm})$ & $2.28 \pm 1.1$ \\
Preoperative OR \pm SD & $0.62 \pm 0.16$ \\
Preoperative ER PT deficit \pm SD & $38 \pm 29$ \\
Preoperative ER TW deficit \pm SD & $56 \pm 41$ \\
Preoperative IR PT deficit \pm SD & $28 \pm 24$ \\
Preoperative IR TW deficit \pm SD & $44 \pm 32$ \\
\hline
\end{tabular}

SD: standard deviation, OR: occupation ratio (supraspinatus muscle / supraspinatus fossa), ER: external rotation, PT: peak torque, TW: total work, IR: internal rotation

Table 2. Sugaya classification of the rotator cuff status after repair of the rotator cuff by magnetic resonance imaging

\begin{tabular}{lcc}
\hline \hline Sugaya type & Number & Retear \\
\hline I (Sufficient thickness with homogenous low intensity) & 21 & No $68 \%$ \\
II (Sufficient thickness with partial high intensity) & 20 & Yes $32 \%$ \\
III (Insufficient thickness without discontinuity) & 6 & 16 \\
IV (Presence of a minor discontinuity) & 6 & \\
V (Presence of a major discontinuity) & 6 \\
\hline
\end{tabular}

Table 3. Comparison between two groups $(n=69)$ were available for follow-up MRI

\begin{tabular}{lcc}
\hline \hline & Group I (Intact group, $\mathrm{n}=47)$ & Group II (Retear group, $\mathrm{n}=22)$ \\
\hline Tear size \pm SD $(\mathrm{cm})$ & $2 \pm 0.9$ & $2.9 \pm 1.2$ \\
Preoperative OR \pm SD & $0.67 \pm 16$ & $0.60 \pm 15$ \\
Preoperative ER PT deficit \pm SD & $39 \pm 30$ & $44 \pm 26$ \\
Preoperative ER TW deficit \pm SD & $54 \pm 00$ & $58 \pm 38$ \\
Preoperative IR PT deficit \pm SD & $21 \pm 21$ & $36 \pm 26$ \\
Preoperative IR TW deficit \pm SD & $36 \pm 00$ & $51 \pm 35$ \\
\hline
\end{tabular}

SD: standard deviation, OR: occupation ratio (supraspinatus muscle / supraspinous fossa), ER: external rotation, PT: peak torque, TW: total work, IR: internal rotation. 
Table 4. Comparison of isokinetic test preoperatively and postoperatively between two groups ( $\mathrm{n}=32$ ) were available for follow-up MRI with postoperative isokinetic strength test

\begin{tabular}{llcccc}
\hline \hline & & ER PT deficit & ER TW deficit & IR PT deficit & IR TW deficit \\
\hline Group A (Intact group, $\mathrm{n}=24)$ & Preoperatively & $35 \pm 28$ & $57 \pm 33$ & $21 \pm 23$ & $36 \pm 28$ \\
& Postoperatively & $18 \pm 20$ & $25 \pm 35$ & $3 \pm 19$ & $6 \pm 34$ \\
Group B (Retear group, $\mathrm{n}=8)$ & Preoperatively & $43 \pm 25$ & $60 \pm 27$ & $33 \pm 15$ & $49 \pm 18$ \\
& Postoperatively & $20 \pm 21$ & $25 \pm 34$ & $10 \pm 16$ & $13 \pm 25$ \\
\hline
\end{tabular}

ER: external rotation, PT: peak torque, TW: total work, IR: internal rotation.
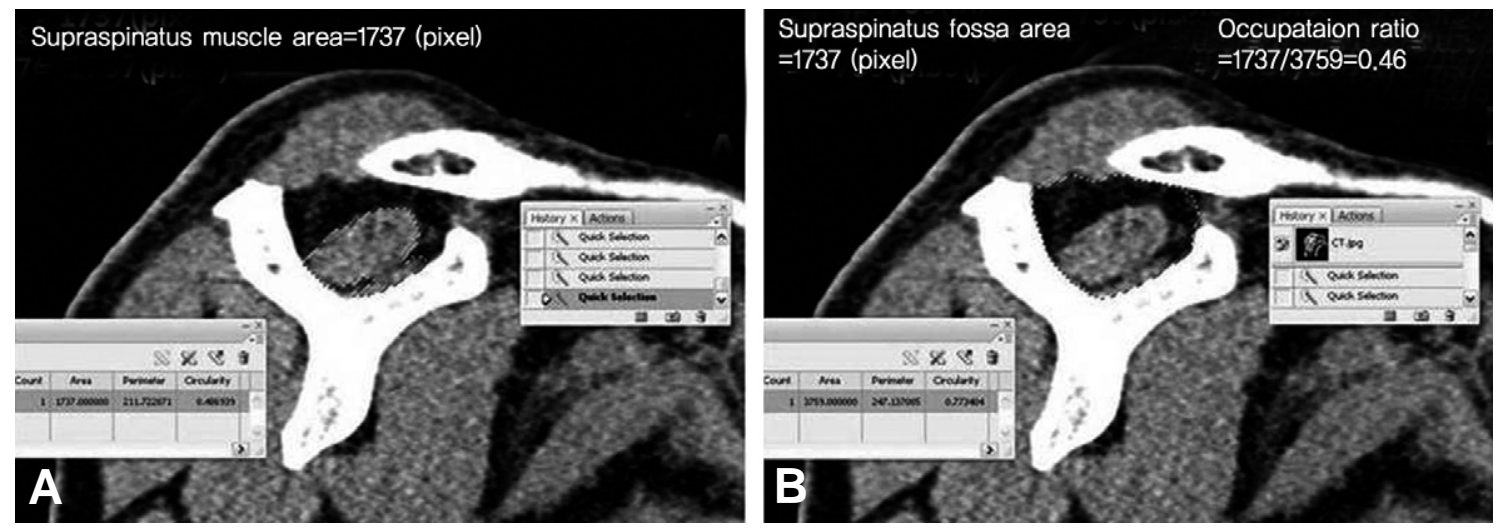

Fig. 1. Calculation of the occupation ratio by dividing the area of the supraspinatus muscle (A) by that of the supraspinous fossa (B) using Photoshop on a multidetector CT oblique sagittal image.

의 통증 및 근력 약화 등, 건측의 정확한 근력검사가 어려웠던 경우도 제외하였다.

\section{2. 연구 방법}

1) 해부학적 요소 측정 및 수술 방법

극상근의 점유율은 극상 와의 면적에 대한 극상근 면 적의 비율로서, 극상근의 힘살부분을 가장 잘 볼 수 있 도록 오구돌기 기저부 내측 경계부위의 사 시상면 영상 에서 구하였다. 극상 와의 경계는 견갑 극의 근위 경계 에서부터 쇄골과 견봉의 원위 경계까지로 정하였다. 극 상 와와 극상근의 크기 측정에는 Photoshop CS3 (Adobe Systems Incorporated; San Jose, California)의 magic selection tool과 measurement tool을 이용하였다. 이는 유사한 음영을 갖는 pixel을 자동으로 선택하도록 하여 선택된 pixel의 수를 측정하 여 면적을 계산하는 방법 (Fig. 1)으로 측정하였다. ${ }^{13)}$

파열의 크기는 관절경 수술 중 파열된 건의 변연부에 대한 최소한의 절제술 후 눈금이 매겨진 소식자 (calibrated probe)를 이용하여 전후 길이를 측정하였다.

수술은 한 집도의에 의해 시행되었으며 모든 예에서 견봉 성형술과 함께 관절경적 이열 복원술 또는 광범위 근개 봉합술 (massive cuff stich)을 시행하였다.

\section{2) 등속성 근력검사}

Biodex $^{\circledR}$ Isokinetic Dynamometer (Model 900240, Biodex Corporation, Shirley, NY, USA)를 이용하여 회전근 개의 등속성 근력을 측정하였다. 모든 환자는 검사전 5 분간의 스트레칭을 한 후 $60^{\circ}$ /초 각속 도로 각각 5 회씩 반복 연습을 시행하였다. 환자를 기구 에 편한 자세로 앉힌 후 가슴 앞쪽으로 지지대를 적용 하여 상체를 고정시키고 어깨는 견갑골 면의 전방 거상 30 도 위치에서 주관절을 90 도 굴곡하고 외회전과 내회 전을 최대 근력으로 $60^{\circ}$ /초 각속도에서 5 회 시행하여 건측과 비교하여 최대 우력 및 총 일의 양에서의 결손 치를 기록하였다 (Fig. 2).

\section{3) 통계 분석}

회전근 개의 해부학적 요소와 등속성 근력검사의 상 관관계를 얻기 위해 Pearson 선형상관계수 (Pearson correlation linear coefficient)를 구하였고 완전 치 유된 군과 재파열된 군의 비교는 Mann-Whitney 검 정 및 경향분석법인 선형대 선형 결합방법으로 평가하 였다. 통계처리는 SPSS (SPSS Inc., Chicago, Illinois, USA) version 12.0 을 사용하였으며 $\mathrm{p}$-value 가 0.05 보다 작을 때 통계적으로 유의한 것으로 판정하 였다. 


\section{결 과}

수술 전 등속성 근력검사 및 자기공명영상검사를 시 행한 97예에서 남자가 48예, 여자가 49예였으며 평균 연령은 54 세였다. 파열의 크기는 평균 $2.28 \pm 1.1 \mathrm{~cm}$, 수술 전 극상근의 점유율은 평균 $0.62 \pm 0.16$ 였다 (Table 1). 파열의 크기와 극상근의 점유율간 Pearson 선형상관계수는 $-0.513(p=0.000)$ 로 통계적으로 유의한 음의 상관관계를 보여 파열의 크기가 클수록 극 상근의 지방변성 정도가 심한 것을 보여주었다 (Fig. 3). 수술 전 외회전 및 내회전의 최대 우력 및 총 일의 양에서의 결손은 외회전은 평균 $38 \% \pm 29,56 \% \pm 41$ 였 고 내회전은 $28 \% \pm 24,44 \% \pm 32$ 였다. 수술 전 외회전

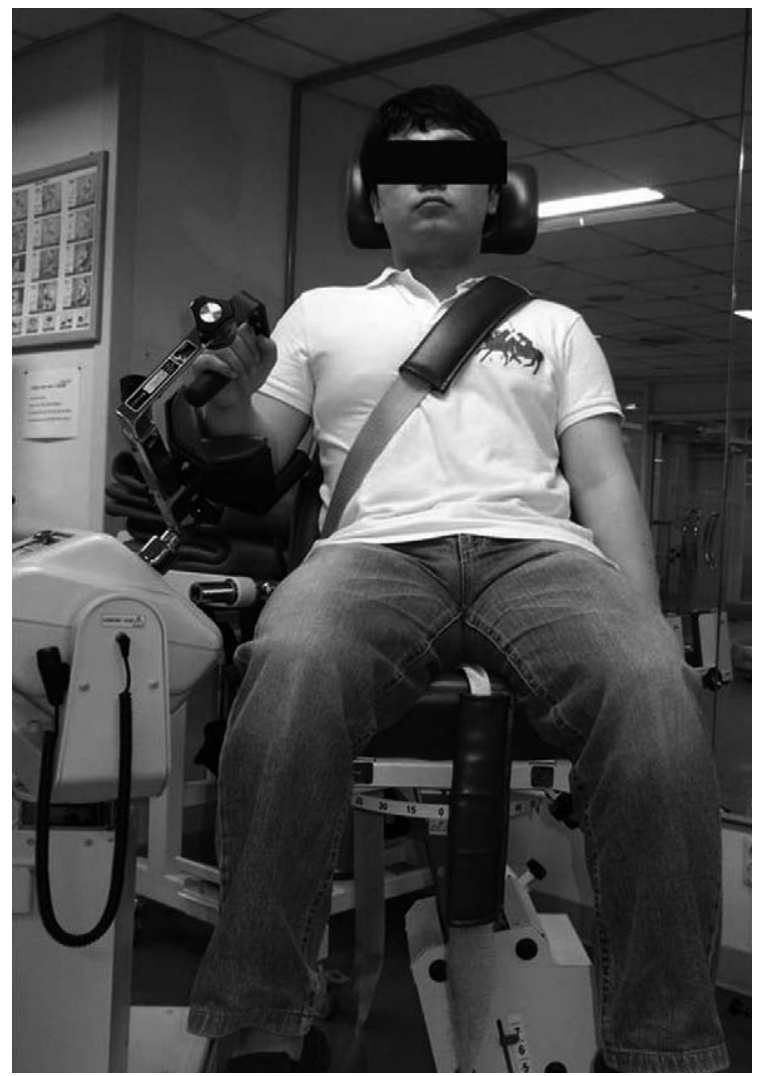

Fig. 2. The position of isokinetic muscle strength test for shoulder external and internal rotation.
의 최대 우력과 총 일의 양에서의 결손과 파열의 크기 와의 Pearson 선형상관관계수는 $0.407 \quad(p=0.000)$, $0.484(p=0.000)$ 였으며 내회전의 최대 우력과 총 일의 양에서의 결손과의 Pearson 선형상관계수는 0.432 $(p=0.000), 0.512(p=0.000)$ 로 양의 상관관계를 보여 파열의 크기가 클수록 등속성 근력 결손이 유의하게 증 가하였다 (Table 5). 점유율과 외회전의 최대 우력 및 총 일의 양에서의 결손에 대한 상관계수는 -0.286 $(p=0.005),-0.293(p=0.004)$ 였으며 내회전의 최대 우 력 및 총 일의 양에서의 결손에 대한 상관계수는 $0.266(p=0.009),-0.320(p=0.001)$ 로 극상근의 지방 변성과 등속성 근력 결손은 약한 상관관계를 보였다 (Table 5).

수술 전 등속성 근력검사 및 추시 자기공명영상검사 를 시행한 69예 중 완전 치유된 군은 47예 (sugaya 1 형 21, 2형 20, 3형 6), 재파열된 군은 22예 (sugaya 4형 16, 5형 6)을 비교하였다. 두 군의 나이는 각각 평 균 56세, 57 세 였으며 파열의 크기는 $2 \mathrm{~cm}, 2.9 \mathrm{~cm}$, 극상근 점유율은 $0.67,0.60$ 였다. 두 군에서 파열의 크기와 극상근의 점유율은 통계적으로 유의한 차이를

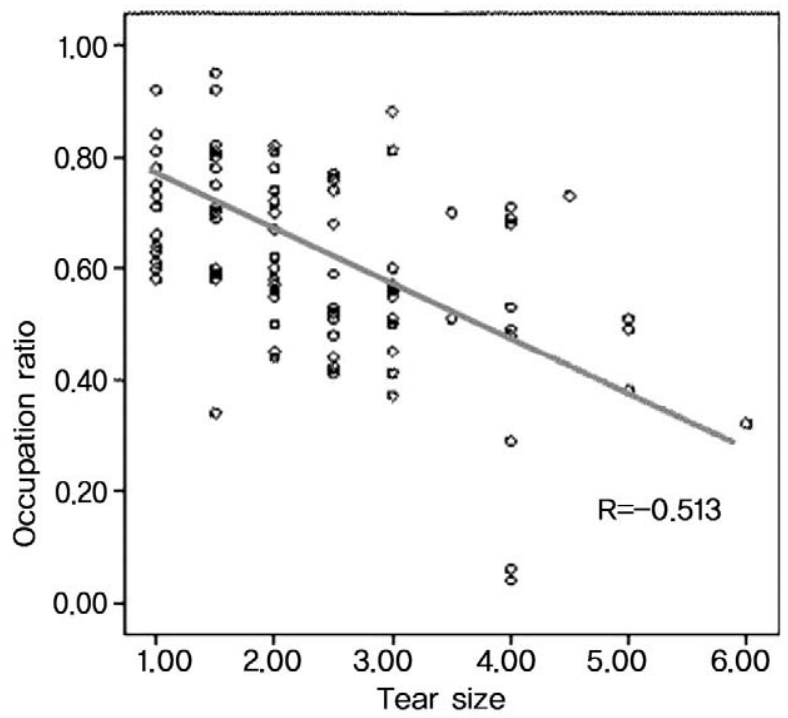

Fig. 3. The graph shows negative correlation between cuff tear size and occupation ratio.

Table 5. Pearson correlation coefficient between tear size, occupation ratio of supraspinatus muscle and preoperative isokinetic strength deficit

\begin{tabular}{lcc}
\hline \hline Isokinetic strength deficit & CC with tear size & CC with occupation ratio \\
\hline Preoperative ER PT deficit & $0.407(p=0.000)$ & $-0.286(p=0.005)$ \\
Preoperative ER TW deficit & $0.484(p=0.000)$ & $-0.293(p=0.004)$ \\
Preoperative IR PT deficit & $0.432(p=0.000)$ & $-0.266(p=0.009)$ \\
Preoperative IR TW deficit & $0.512(p=0.000)$ & $-0.320(p=0.001)$ \\
\hline
\end{tabular}

CC: correlation coefficient, ER: external rotation, PT: peak torque, TW: total work, IR: internal rotation. 
보였다 $(p=0.037,0.036)$. 두 군의 수술 전 외회전 최 대 우력의 결핍은 평균 $39 \%, 44 \%$ 였으며 총 일의 양에 서의 결손은 평균 $54 \%, 58 \%$ 로 유의한 차이는 보이지 않았다 $(p>0.05)$.

수술 전과 후 자기공명영상검사 및 등속성 근력검사 모두를 시행하였던 32예에서 수술 후 등속성 근력 결손 은 유의하게 감소하였다 $(p=0.00)$. 완전 치유된 경우 된 $\mathrm{A}$ 군에서는 수술 전에 비해 수술 후의 외회전 최대 우력 및 총 일의 양에서의 결손은 $17 \%, 32 \%$ 의 감소 를 보였고 재파열된 $\mathrm{B}$ 군에서는 각각 $23 \%, 35 \%$ 감소 를 보였으나 두 군사이의 통계적인 차이는 없었다 ( $p>0.05)$ (Fig. 4).

\section{고 찰}

회전근 개 파열에서 힘의 전달의 소실에 따른 등속성 근력의 감소는 건측에 비해 $37 \sim 70 \%$ 로 다양하게 보고 되고 있다. ${ }^{7.1415)}$ 본 연구에서는 등속성 근력은 파열의 크기와는 높은 상관관계를 보였으나 극상근의 지방변성 과는 약한 상관관계가 있었다. 파열의 크기가 클수록 등속성 근력의 결손이 크게 나타났다. 파열의 크기가 작은 경우는 파열된 가장자리를 통해 힘의 일부가 전달 되며 ${ }^{16)}$ 파열의 크기가 클수록 극상근 뿐만 아니라 주 기 능이 외회전인 극하근의 파열도 동반함으로써 등속성 근력 결손이 더 클 것으로 생각된다. ${ }^{17-19)}$

극상근의 지방변성은 극상 와 (supraspinous fossa) 의 면적에 대한 극상근 면적의 비율로서 근육의 실제 부피와 높은 상관관계를 보이며 근위축의 평가에 최근 많이 사용된다. ${ }^{20)}$ 점유율 영상처리 프로그램인 Photoshop (Adobe Systems Incorporated; San Jose, California)의 magic selection tool을 이용하여 극상
와 및 근육의 구역이 자동적으로 지정되도록 하여 점유 율을 계산하는 방법이 우수한 재생성을 보여 극상근의 지방변성을 좀 더 정확하게 평가할 수 있었다. ${ }^{13)}$ 극상근 은 주로 견관절의 초기 외전에 관여하고 있으나 극상근 결손은 극하근 결속시와 비슷한 정도로 외회전에 영향 을 줄 수 있다고 알려져 있다. ${ }^{21-24)}$ 그러나 본 연구에서 는 극상근의 점유율과 외회전 및 내회전의 등속성 근력 은 의미 있는 상관관계를 보이지 않았다.

재파열된 군과 완전 치유된 군의 수술 전 극상근의 점유율, 파열의 크기, 나이, 성별, 외회전근의 근력 및 기능 점수 등을 비교하였다. 나이와 성별에서는 유의한 차이를 보이지 않았지만 재파열된 군에서 파열의 크기 가 컸으며 극상근의 점유율도 낮게 나왔다. 수술 전, 후 시행한 등속성 근력검사는 두 군 간의 차이는 없었 다. 또한 근력에 회복에 있어서도 통계적으로 차이는 없었다. 따라서 수술 전 등속성 근력검사에서 보이는 근력 결손이 클수록 수술 후 재파열이 잘 발생한다고 할 수 없으며 재파열 또한 등속성 근력검사에 영향을 주지 못하였다. 이는 수술 전 근력검사에서 통증으로 인해 최대 힘을 발휘할 수 없어 근력이 낮게 측정 되었 으며 수술 후에는 통증 감소로 인해 근력이 증가한 것 으로 생각된다. ${ }^{25}$ 실제 몇몇 연구에서 견봉하 국소 마취 제 주입에 의한 통증 차단은 회전근 개 파열 환자의 근 력을 증가 시킬 수 있다고 하였다. ${ }^{26)}$

회전근 개 질환에서 등속성 근력검사는 견관절 근력 을 분석하는 유용하고 객관적인 검사방법이다. 검사 기 계의 원리는 미리 설정해 놓은 각속도를 초과하기 위한 힘을 동력계 축의 모멘트로 변환하여 기록하는 것이 다. ${ }^{27-29)}$ 따라서 환자가 미리 설정된 각속도에 도달하지 못하면 0 으로 기록되어 건측에 비해 $100 \%$ 결손으로 의 미 없는 검사가 된다. 또한 통증이 심한 경우, 검사 자
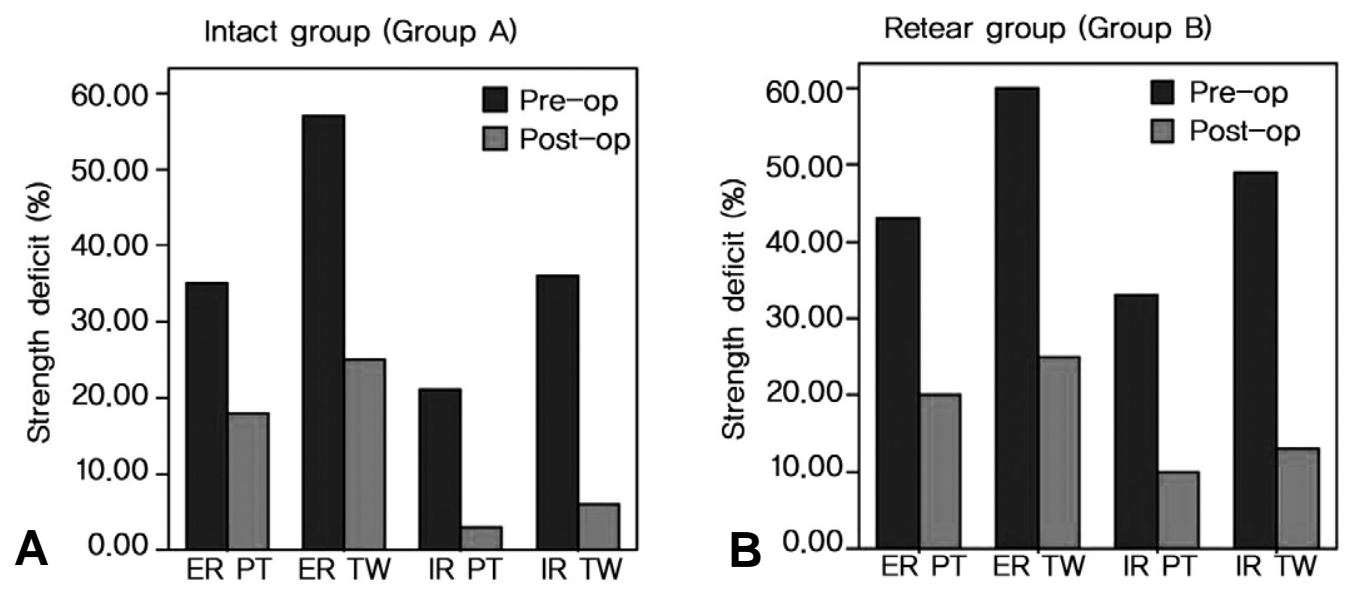

Fig. 4. (A, B) The graph shows the isokinetic strength deficit was improved markedly in group A and group B. But there was no statistical difference between two groups. ER: external rotation, IR: internal rotation, PT: peak torque, TW: total work. 
세를 취하지 못하는 경우, 관절 운동 범위의 제한 등의 문제가 있으면 설정속도에 도달하지 못하게 된다. 본 연구에서도 심한 통증이 있는 환자, 현저한 근력 저하 가 있는 환자 및 견관절 구축 환자는 $60^{\circ}$ /초 각속도에 도달하지 못해 검사에서 제외되었다.

그러나 측정 방법에 있어서 환자의 자세나 기계의 각 속도 설정 등에 대한 적절한 기준이 없다. ${ }^{30)}$ 등속성 근 력검사 기계에서 각속도를 고속도로 설정할 경우에는 환자의 힘을 충분히 반영하지 못하며, 저속도일 경우에 는 저항이 환자의 힘 보다 커서 검사를 진행할 수가 없 다. 따라서 많은 연구를 통해 검사를 위한 적절한 각속도 의 설정이 필요하다. 또한 근력검사는 환자의 노력에 따 라 달라지므로 검사 전의 통증 정도와 검사에 대한 환자 의 순응도가 중요하다. 등속성 근력검사는 실제 근력의 약화와 통증에 의한 약화를 구분하지 못하며 환자에게 최대한 힘으로 검사를 시행할 수 있게 격려하나 통증이 있는 고령의 환자에서는 쉽지 않은 검사가 된다.

연령의 증가에 따른 건 내의 퇴행성 변화로 자기 공 명 영상 또는 초음파를 이용한 전향적인 연구 결과 60 대 이상에서 전층 파열의 빈도가 $28 \%, 70$ 대 이상에서 $65 \%$ 의 빈도를 보인다고 하여 고령에서 회전근 개 파열 의 빈도가 급격히 증가함을 보여주고 있다. ${ }^{31)}$ 이와 같은 노화 현상에 의한 퇴행성 변화는 결국 회전근 개 파열 을 유발하지만 회전근 개 파열이 증상을 동반하지 않는 경우도 많아 고령에서의 등속성 근력 검사에서 건측과 비교해서 구한 근력 결손이 정확하지 않을 수 있다.

본 연구의 제한점으로는 등속성 근력검사 전 통증 조절을 하지 않았던 것과 외전과 전방 거상에 대한 검 사가 시행되지 않았고 파열에 있어 견갑하 건의 파열 유무 및 동반 병변에 따른 비교가 없었던 점이다. 또한 회전근 개 파열의 봉합 방법에 따른 분류가 되지 않았 으며 수술 전, 후 모두에서 등속성 근력검사를 시행한 환자 수가 많지 않았던 점이다.

\section{결 론}

회전근 개 파열에 있어 파열의 크기는 등속성 근력검 사와의 높은 상관 관계를 보이나 근육의 지방변성, 수 술 후의 건의 연속성과는 낮은 상관 관계를 보였다. 정 확한 등속성 근력검사를 위해 적절한 통증 조절과 검사 를 위한 자세 및 각속도 설정 등에 대한 연구가 필요할 것으로 사료된다.

\section{REFERENCES}

1) Bassett RW, Cofield RH. Acute tears of the rotator cuff. The timing of surgical repair. Clin Orthop. 1983;
175: 18-24.

2) Cofield RH. Rotator cuff disease of the shoulder. $J$ Bone Joint Surg Am. 1985;67:974-9.

3) EIIman H, Hanker G, Bayer M. Repair of the rotator cuff. End-result study of factors influencing reconstruction. J Bone Joint Surg Am. 1986;68:1136-44.

4) Hawkins RJ, Misamore GW, Hobeika PE. Surgery for full thickness rotator cuff tears. J Bone Joint Surg Am. 1985;67:1349-55.

5) Wolfgang GL. Surgical repair of tears of the rotator cuff of the shoulder. J Bone Joint Surg Am. 1974;56: 14-26.

6) Gore DR, Murray MP, Sepic SB, Gardner GM. Shoulder muscle strength and range of motion following surgical repair of full thickness rotator cuff tears. $J$ Bone Joint Surg Am. 1986;68:266-72.

7) Rabin SI, Post M. A comparative study of clinical muscle testing and Cybex evaluation after shoulder operations. Clin Orthop Relat Res. 1990;258:147-56.

8) Walker SW, Couch WH, Boester GA. Isokinetic strength of the shouldel after repair of a torn rotator cuff. J Bone Joint Surg Am. 1987;69:1041-4.

9) George J. Davies, Todd S. Ellenbecker, Kevin E. Wilk. Isokinetic testing and rehabilitation of the shoulder complex. The Athlete's shoulder. 2nd ed. Churchill Livingstone; 2009.719-47.

10) Marino M, Nicholas JA, Gleim GW, Rosenthal P, Nicholas SJ. The efficacy of manual assessment of muscle strength using a new device. Am J Sports Med. 1982;10:360-4.

11) Reid DC, Oedekoven G, kramer JF, Saboe LA. Isokinetic muscle strength parameters for shoulder movements. Clin Biomech. 1989;4:97.

12) Sugaya H, Maeda K, Matsuki K, Moriishi J. Functional and structural outcome after arthroscopic full thickness rotator cuff repair: single-row versus dualrow fixation. Arthroscopy. 2005;21:1307-16.

13) Tae SK, Oh JH, Kim SH, Chung SW, Yang JY, Back YW. Evaluation of fatty degeneration of the supraspinatus muscle using a new measuring tool and its correlation between multidetector computed tomography and magnetic resonance imaging. Am J Sports Med. 2011;39:559-606.

14) Kirschenbaum D, Coyle MP Jr, Leddy J, et al. Shoulder strength with rotator cuff tears: pre- and postoperative analysis. Clin Orthop. Relat Res. 1993; 288:174-8.

15) Ben-Yishay A, Zuckerman JD, Gallagher M, Cuomo F. Pain inhibition of shoulder strength in patients with impingement syndrome. Orthopedics. 1994;17:685-8.

16) Burkhart SS. Reconciling the paradox of rotator cuff repair versus debridement: a unified biomechanical rationale for the treatment of rotator cuff tears. Arthroscopy. 1994;10:4-19. 
17) Tae SK, Kim JY, Park JS. MRI follow-up study after arthroscopic repair of multiple rotator cuff tendons. $J$ Korean Shoulder Elbow Soc. 2008;11:96-103.

18) Clark JM, Harryman DT II. Tendons, ligaments, and capsule of the rotator cuff: gross and microscopic anatomy. J Bone Joint Surg Am. 1992;74:713-25.

19) Minagawa H, Itoi E, Konno N, et al. Tendon attachment of the supraspinatus and infraspinatus to the humerus: an anatomical study. Nippon Seikeigekagakkai Zasshi. The 2nd Academic Congress, Asian Shoulder Association, Perth 1996;70:S423. (In Japanese).

20) Tingart MJ, Apreleva M, Lehtinen JT, Capell B, Palmer WE, Warner JJP. Magnetic resonance imaging in quantitative analysis of rotator cuff muscle volume. Clin Orthop Relat Res. 2003;415:104-10.

21) Howell SM, Imobersteg AM, Seger DH, Marone PJ. Clarification of the role of the supraspinatus muscle in shoulder function. J Bone Joint Surg Am. 1986;68:398404.

22) Itoi E, Minagawa H, Sato T, Sato K, Tabata S. Isokinetic strength after tears of the supraspinatus tendon. J Bone Joint Surg Br. 1997;79:77-82.

23) Kuhlman JR, Iannotti JP, Kelly MJ, Riegler FX, Gevaert ML, Ergin TM. Isokinetic and isometric measurement of strength of external rotation and abduction of the shoulder. J Bone Joint Surg Am. 1992;
74:1320-33.

24) Otis JC, Jiang CC, Wickiewicz TL, Peterson MG, Warren RF, Santner TJ. Changes in the moment arms of the rotator cuff and deltoid muscles with abduction and rotation. J Bone Joint Surg Am. 1994; 76:667-76.

25) Ben-Yishay A, Zuckerman JD, Gallagher M, Cuomo F. Pain inhibition of shoulder strength in patients with impingement syndrome. Orthopedics. 1994; 17:685-8.

26) Park JY, Lee WS, Lee ST. The strength of the rotator cuff before and after subacromial injection of lidocaine. J Shoulder Elbow Surg. 2008;17:8-11.

27) Basmajian JV. Therapeutic Exercise. Baltimore. 4th ed. Williams and Wilkins;1984. 88.

28) Ivey FM, Calhoun JH, Rusche K, Bierschenk J. Isokinetic testing of shoulder strength: Normal values. Arch Phys Med Rehabil. 1985;66:384.

29) Mccardle WD, Katch FI, Katch VL. Exercise physiology. Energy, nutrition and human performance. Philadelphia: Lea \& Febiger; 1981.288-94.

30) Elsner RC, Pedegana LR, Lang J. Protocol for Strength Testing and Rehabilitation of the Upper Extremity. J Orthop Sports Phys Ther.1983;4:229-35.

31) Kim YG. Controversy in pathophysiology of rotator cuff tear: Degenerative Tear. J Korean Shoulder Elbow Soc. 2008;11:71-86. 


\section{초 록}

목적: 수술적으로 치료한 회전근 개 파열에서 파열의 크기, 극상근의 지방변성 및 추시 자기공명 영상검사상에서 복원 유지 여부 등의 해부학적 상태와 등속성 근력검사의 상관 관계를 알아보고 자 하였다.

대상 및 방법: 회전근 개 파열로 수술 받은 환자 중 수술 전 자기공명영상검사 및 등속성 근력검 사, 수술 후 평균 10 개월에 시행한추시 자기공명영상검사 및 등속성 근력검사의 자료가 있는 32 예를 대상으로 하였다. 등속성 근력검사는 외회전, 내회전의 근력을 $60 \% / \mathrm{sec}$ 에서 환측의 최대 우력 및 총 일의 양을 건측과 비교하여 결손치를 측정하였다.

결과: 파열의 크기가 클수록 수술 전 등속성 근력 결손이 유의하게 증가되었다 $(p<0.001)$. 수술 전 극상근의 점유율과 등속성 근력 결손은 낮은 상관 관계를 보였다 $(p<0.001)$. 추시 자기공명영 상검사상 완전 치유된 군에서 수술 전 외회전의 최대 우력 및 총 일의 양에서의 결손은 각각 $39 \%, 54 \%$ 였고, 재파열된 군은 각각 $44 \%, 58 \%$ 로 통계적으로 차이는 없었다. 수술 후 외회전의 최대 우력과 총 일의 양에서의 결손은 완전 치유된 군에서 각각 $17 \%, 32 \%$ 감소하였으며, 재파열 된 군은 $23 \%, 35 \%$ 의 감소를 보였지만 두 군간에 유의한 차이는 없었다 $(p>0.05)$.

결론: 수술 전의 등속성 근력검사는 파열의 크기와 높은 상관 관계를 보이나 근육의 위축을 반영 하지는 못하며, 수술 후 건의 재파열과도 상관 관계가 없었다. 수술 후 건의 연속성 여부는 수술 후의 등속성 근력검사에 영향을 주지 않았다.

색인 단어: 회전근 개, 극상근, 지방변성, 재파열, 등속성 근력검사 